\title{
Effectiveness of the Early Childhood Development Programme on Grade One Performance in Mathematics and English Language in Mzilikazi District (Bulawayo).
}

\author{
Sibanda Patrick \\ (Lecturer and Programme Coordinator in the Department Of Disability Studies and Special Needs Education, \\ Zimbabwe Open University).
}

\begin{abstract}
This study sought to investigate the effectiveness of the Early Childhood Development (ECD) programme on grade one performance in Mzilikazi District in Bulawayo. Papalia, Olds and Feldman (2001) observed that children who have been through ECD programmes generally excelled in basic academic skills while Smith (1994) suggested that ineffective ECD programmes led to fragmented and wide variation in the quality of early primary school education. The study was quantitative in nature and used a cross-sectional survey and the ex-post facto research designs. Two independent samples of 100 grade one children each, 20 grade one teachers and 10 administrators participated in the study. Mathematics and English Language selfdesigned tests were used with the children while structured questionnaires were used with teachers and administrators. Data were presented on tables and analysed using the Likert Scale, descriptive and inferential statistics. Indications from qualitative data were that the ECD programme was not effective on grade one performance in both subjects. A t-test of independent means confirmed that, there was no difference in performance in Mathematics between grade one children who underwent the ECD programme and those who did not. However, in English Language the t-test indicated a significant difference in performance between the two groups. On these bases, the research concluded that the ECD programme in Mzilikazi District was not effective on grade one performance in Mathematics but was effective on English Language performance. The study then recommended increased financial, material, human resource and infrastructural support of the ECD programme and review of the ECD curriculum
\end{abstract}

Keywords: - Early childhood, Early Childhood Development Programme, Holistic development

\section{BACKGROUND TO THE STUDY}

Historically, child-care programmes had tended to focus on provision of mere nursery care. However, current international trends prefer a broader view of early childhood development programmes which respond to holistic development of the child. In Zimbabwe, the emergence of the Early Childhood Development (ECD) Programme has increased the demand for periodic evaluations of the effectiveness of the programme. Ayasi (2003), however, observed that, the main activities of the policy frameworks on early childhood and care programmes in Zimbabwe were centered on resource and service provision not scholastic performance. Most of the studies that have been conducted on ECD have either been in America or Europe and then customized to Africa. Howes (1986) and National Education Policy Investigation (1992) suggest that, after all, most of these studies have concentrated only on qualitative issues of diversity and accessibility at the expense of quality and effectiveness. Quite recently, an evaluation study of the ECD programme in Zimbabwe was conducted by Dyanda, Makoni, Madukati and Kuyayana (2005). The purpose of the study was to review the history of the ECD programme in Zimbabwe, to assess the implication for the new policy and to propose a new policy framework. Earlier on, a baseline study by the Ministry of Education, Sports and Culture in 1996 and a subsequent evaluation study by the same ministry in 1997, also only concentrated on the margin of provision and accessibility (Nziramasanga, 1999). Seemingly, none of these studies explored whether the ECD programme contributed to quality primary school learning and performance and, if anything, measured effectiveness of the programme on grade one performance. The current study diverged from the thrust of the earlier studies, to investigate the effectiveness of the ECD programme on the school performance of grade one pupils in Mzilikazi District in Bulawayo. The study focused on Mathematics and English Language performance.

\subsection{Statement of the Problem}

Early Childhood Development Programmes in Zimbabwe have, according to previous researchers, been characterized by poor quality provision of services and resources (Ministry of Education, Sport and 
Culture (MOESC, 1996\& 1997) ;Nziramasanga, 1999). No change in the scholastic performance of grade one children in Bulawayo as a result of the ECD programme has been observed or reported, raising concern as to whether the programme is effective on school performance.

\subsection{Research Questions}

- How effective is the ECD programme on grade one performance in Mathematics and English Language in Mzilikazi District?

- How do grade one children in Mzilikazi District who underwent the ECD programme perform in Mathematics and English Language?

1.4 Hypotheses

$\mathrm{H}_{\mathrm{o}}$ : There is no difference in performance in English Language between the grade one children in Mzilikazi District who underwent the ECD programme and those who did not.

$\mathrm{H}_{1}$ : There is a difference in performance in English Language between the grade one children in Mzilikazi District who underwent the ECD programme and those who did not.

$\mathrm{H}_{\mathrm{o}}$ : There is no difference in performance in Mathematics between the grade one children in Mzilikazi District who underwent the ECD programme and those who did not.

$\mathrm{H}_{1}$ : There is a difference in performance in Mathematics between the grade one children in Mzilikazi District who underwent the ECD programme and those who did not.

\subsection{Primary Purpose of the Study}

This study sought to establish the effectiveness of the ECD programme on school performance of grade one children in Mzilikazi District (Bulawayo) in Mathematics and English Language.

\subsection{Conceptual Framework (Literature Review) \\ 1.6.1 Conceptions of Early Childhood Development Programme}

The notion of the early childhood education has grown out of Jean Jacques Rousseau (1712-1778)'s philosophy of progressivism. The dynamic evolutionary process of early childhood education and the ensuing influences on the rise of ECD programmes has necessitated various ways of conceptualizing ECD programmes. Feeney, Christensen and Moravick (1991:51) see the term early childhood education as broadly referring to, 'efforts to educate and care for young children in schools, centers and homes'. According to this conception, early childhood means the years that children attend pre-school, typically from ages 3 to 5 years (Santrock, 2002). In the same context, pre-school is a term generally used to describe programmes that grew out of the legacy of Margaret McMillan's nursery school and that are designed to promote early childhood development (Hurst, 1991). According to Ayasi (2003), there has been a growing tendency to conceive ECD as a preparatory stage for serious learning at grade one. Earlier own, Hendrick (1986) noted that, most members of the general public, including parents and legislators, were uninformed about the potential value of ECD while some saw it as mere baby-sitting. However, Harmse, duToit and Broeksma (1984:14), argued that, ECD refers to, "....appropriately adapted activities designed and conducted to meet the needs of those children who have already outgrown their early infancy, but have not yet reached the school age." Santrock (2002), elaborates that, somehow, ECD programmes are those that prepare children for primary school education. Two schools of thought emerge from the foregoing conceptions. One of the schools designates ECD as provision of academically oriented educational activities appropriate for young children so that they become literally and numerically ready for grade one (Morrison, 1988). The other school sees ECD as a broader developmental activity that encompasses care and age appropriate educational activities that are nevertheless not academic in content and process.

The contemporary definition of the ECD programme conceptualise care and education as indivisible. Dichotomisation of ECD programme into care and education is actually detrimental to child development in the current conceptualization. As early as the $18^{\text {th }}$ century, the distinction between care and education was already being internationally recognized as artificial. Jean Jacques Rousseau's philosophy of progressivism effectively encompasses both the care and educational dimension of ECD. Thus, ECD should be based on educational and procedural planning and be generated and justified by reference to the whole process of human development (Papalia, et al, 2001). The current research adopted the view that an ECD programme entails efforts to educate and care for young children and to facilitate their overall development including deliberate inculcation of intellectual skills necessary for primary school learning. Previous research has shown that, early childhood educational activities that subscribe to the notion of education as development laid the best foundation for literacy (Payton, 1984; Wells, 1985), numeracy (Hughes, 1986) and scientific understanding (Richards, Collis and Koncaid, 1986). In other words, the developmental view of ECD according, to Morrison (1988), confirms 
that, effective early childhood education promotes academic excellence at primary school level and even beyond.

\subsubsection{Evolution of the ECD Policy in Zimbabwe}

After independence in 1980, the Government of Zimbabwe, through the then Ministry of Education, Sport and Culture (MOESC) launched a strong campaign for the establishment of what were then termed Early Childhood Education and Care (ECEC) centers particularly in rural areas. This was in response to emerging socio-economic challenges. MOESC (1999) reports that most of the centres operated under trees and were manned by untrained personnel. The initial establishment of the ECEC centers in Zimbabwe was guided by principles of philanthropic socialism (Ayasi, 2003), since the centers were mere play of feeding points for young children.

At its inception, the ECEC programme was community-based (MOESC, 1999) but the 2004 National Early Childhood Development (NECD) policy designates government as more directly responsible for early childhood development (Dyanda, et al, 2005). In this way, rapid socio-economic changes of the time created conditions which required new ways of thinking about and of maintaining ECD services in Zimbabwe. Consequently, Statutory Instrument 72 of 1999 which repealed the pre-independence Statutory Instrument 72 of 1973 set out new conditions under which ECEC centers that had gone beyond feeding points could be recognized as ECD programmes.

Just like the vision of the Council of Europe (1977), Nziramasanga (1999) recommended vertical continuity between ECD and grade one curricula in Zimbabwean schools. This line of thinking is consistent with the importance of periodic evaluation of the ECD programme on scholastic performance (Ayasi 2003). Taggart and Siraji - Blatchford (2007) believe that, evaluation studies have powerful impact on government policy. Bernard (1973) earlier on declared that, ECD is an explosively growing national concern and as such should be periodically evaluated. According to NEPI (1992:3), "One of the most important tests (evaluation) is whether children who participate in early childhood edu-care programmes are likely to do better at school than those who do not".

The 2004 ECD policy in Zimbabwe, which is also known as the National Early Childhood Development (NECD) programme and is regulated by S.I 106 of 2005, Circular Number 12 of 2005 supports the foregoing proposition and hence designates the ECD programme as formal and school based. From 2005, the Ministry of Education, Sport and Culture '....instituted each government school in Zimbabwe to attach at least two ECD classes for children in the 3 to 5 years age group' (Dyanda et al, 2005:15).

More than two years, the programme's effectiveness on future scholastic performance had not been investigated. This was worrisome as Feeney et al (1991) noted that, a frequently occurring issue in the ECD today is pressure from families for ECD centers to reflect their relevance to elementary school performance. This is more common where parents are poor and are anxious for their young children to demonstrate potential to break the cycle of poverty (Santrock, 2002). The key findings of Taggart and Saraj - Blatchford (2007)'s Effective Provision of Pre-School Education (EPPE) longitudinal studies suggest that the benefits of ECD have significant lasting positive effects on both primary and secondary school performance as well as on overall social development.

Ironically, the Zimbabwe Education Act (1987) paragraph 27, prohibits, '...the teaching in nursery schools (perhaps including the ECD centers) of any subject commonly taught in a school." This would suggest non-co comity between ECD and early primary school curricula in Zimbabwe. In Europe, the major concern has been that the gains in IQ due to ECD programmes hardly lasted beyond the start of grade one (Papalia et al, 2001). Hendrick (1986) posit that, while there is evidence that ECD can produce significant increases in IQ, the increases last only up to 3 years after ECD programme attendance. Curtis (1996) also agrees that, attempts to evaluate the long-term effects of ECD have shown that any gains would washout. However, the author is quick to say that, where follow through in primary school has been maintained, gains persist. In response Santrock (2002) challenges the negative findings, arguing that they have been superceded by new research work.

\subsubsection{Parameters For ECD Programme Effectiveness}

ECD programmes should have some measure of effectiveness. MOESC(1991) reports that, in Zimbabwe, the government's expectation is to standardize approaches to the delivery of quality hence effective ECD programme. According to Hurt, Charlesworth, Burts and DeWolf (1993), ECD programmes that are effective are those that are child-centered and child initiated, well resourced and comprehensive. Thus, the ECD programme should be developmentally appropriate, that is, should be based on children's individual needs, abilities and maturational levels and should have curriculum goals that appeal to all developmental domains (Santrock, 2002). MOESC (2001) envisages that, to achieve such a goal, the physical environment, the resource provisions and the administrative processes of the ECD programme should be positive in out-look and practice. The size of the ECD class, the teacher-pupil ratio, political will and parental and community inputs are other 
crucial factors in the provision of effective ECD programmes. The environment of ECD programme should be safe, attractive, caring, ensuring, stimulating and should include every aspect of the child's experiences (Tassoni, 1998). In addition, policies, the curriculum, multi-disciplinary practices and parental involvement define best practices in the provision of effective ECD services. Quite importantly, Taggart and SirajBlatchford (2007:17) assert, "Attending a high-quality pre-school also protects against the effects of a more poorly performing primary school." By inference, an effective ECD programme is also that which facilitates future excellent school performance of the child.

\section{METHODOLOGY}

The study was quantitative and adopted methodological triangulation involving a cross-sectional survey design and the causal comparative (ex-post facto) research design. Such triangulation was utilized because it led to cost effectiveness and improved data quality (Smith and Kider, 1991). The cross-sectional survey design was used to explore the causal relationship between undergoing the ECD programme and performance in Mathematics and English Language at grade one. Similarly, the ex-post facto design was used since the presumed effect of the ECD programme had already occurred and since it was clear that in dealing with human subjects the study was never going to lend itself to true experimentation (Keyton, 2001).

The population of interest of the study comprised all the 4672 children who were enrolled for grade one in 2008, in the 30 primary schools in Mzilikazi District, all the 90 administrators of the schools, and all the 120 and 60 grade one and ECD teachers respectively. Using multi-stage sampling, 100 children who underwent the ECD programme and the other 100 children who did not undergo the programme were chosen from 10 primary schools constituting two clusters in Mzilikazi District. Fifty percent of the children were girls. The schools were chosen using purposive sampling while the children were chosen by means of stratified random sampling. Ten ECD teachers, 20 grade one teachers and 10 school administrators were chosen through coincidental sampling, that is, depending on their accessibility by the time of the researcher's visit.

Two self-designed assessment tests, one in English Language and the other in Mathematics as well as structured questionnaires were used to gather data. The tests were used with the grade one children while three different structured questionnaires were used to collect responses from the ECD and grade one teachers and from the administrators. Using the Split-Half method via Spearman Brown's Formula, the Mathematics test achieved a reliability coefficient of 0.95 while the English Language test revealed a reliability coefficient of 0.91 . The data were mainly presented on tables and analysed using descriptive and inferential statistics.

\subsection{Findings}

Data were summarized in tables, analysed using frequencies, averages, measures of dispersion and the t-test of independent means.

Table 1: Cross Tabulation by Qualification and Experience of ECD Teachers ( $n=10)$

\begin{tabular}{|llllllll|}
\hline Qualification: & Academic; & Std6/G7 & ZJC & 'O'Level & 'A' Level & Other & Total \\
\hline $\begin{array}{l}\text { Count } \\
\%\end{array}$ & 2 & 1 & 6 & 1 & 0 & 10 \\
& $20 \%$ & $10 \%$ & $60 \%$ & $10 \%$ & $0 \%$ & $100 \%$ \\
& $\begin{array}{l}\text { Profession } \\
\text { al; }\end{array}$ & Untrained & Student & CE/DE(Infant) & CE/DE(General) & Other & Total \\
\hline $\begin{array}{l}\text { Count } \\
\%\end{array}$ & 3 & 2 & 4 & 1 & 0 & 10 \\
Experience & $30 \%$ & $20 \%$ & $40 \%$ & $10 \%$ & $0 \%$ & $100 \%$ \\
\hline $\begin{array}{l}\text { Count } \\
\%\end{array}$ & $0-5 \mathrm{yrs}$ & $6-10 \mathrm{yrs}$ & $11-15 \mathrm{yrs}$ & $16-20 \mathrm{yrs}$ & $20+\mathrm{yrs}$ & \\
\hline
\end{tabular}

Data from Table 1 indicates that the majority of qualified ECD teachers in Mzilikazi District held professional qualifications in either infant or junior primary education. These were also holders of ' $O$ ' Level. A significant number of the teachers were either in training or were untrained. Most of the ECD teachers had less than 10 years experience in early childhood education. From these data, it was evident that the ECD programme in Mzilikazi District was manned by fairly qualified and experienced teachers although they were not spcialist in the area. 
Effectiveness of the Early Childhood Development Programme on Grade One Performance in

Table 2: English Language Test Scores For Children Who Underwent The ECD Programme $\left(\mathbf{n}_{1}=100\right)$

\begin{tabular}{|l|l|l|l|l|l|l|l|l|l|l|}
\hline $\begin{array}{l}\text { Score } \\
(\%)\end{array}$ & $0-20$ & $21-30$ & $31-40$ & $41-50$ & $\begin{array}{l}51- \\
60\end{array}$ & $\begin{array}{l}61- \\
70\end{array}$ & $71-80$ & $81-90$ & $\begin{array}{l}90- \\
100\end{array}$ & $\Sigma$ \\
\hline $\begin{array}{l}\text { Mid } \\
\text { Score } \\
(x)\end{array}$ & 10 & 25.5 & 35.5 & 45.5 & 55.5 & 65.5 & 75.5 & 85.5 & 95.5 & 494 \\
\hline $\begin{array}{l}\text { Frequen } \\
\text { cy }(f)\end{array}$ & 4 & 10 & 6 & 11 & 17 & 21 & 12 & 15 & 4 & 100 \\
\hline$f(x)$ & 40 & 255 & 213 & 500.5 & 943.5 & 1375. & 906 & 1282.5 & 382 & 5898 \\
\hline $\begin{array}{l}(x- \\
\text { mean })\end{array}$ & -48.98 & -33.48 & -23.48 & -13.48 & -3.48 & 6.52 & 16.52 & 26.52 & 36.52 & \\
\hline $\begin{array}{l}(x- \\
\text { mean })^{2}\end{array}$ & $\begin{array}{l}2399 . \\
04\end{array}$ & $\begin{array}{l}1120 . \\
91\end{array}$ & $\begin{array}{l}551.3 \\
1\end{array}$ & $\begin{array}{l}181.7 \\
1\end{array}$ & 12.11 & 42.51 & $\begin{array}{l}272.9 \\
1\end{array}$ & 703.31 & $\begin{array}{l}1333 . \\
71\end{array}$ & $\begin{array}{l}6617.5 \\
2\end{array}$ \\
\hline $\begin{array}{l}f(x- \\
\text { mean })^{2}\end{array}$ & $\begin{array}{l}9596 . \\
16\end{array}$ & $\begin{array}{l}11209 \\
.1\end{array}$ & $\begin{array}{l}3307 . \\
86\end{array}$ & $\begin{array}{l}1998 . \\
81\end{array}$ & $\begin{array}{l}205.8 \\
8\end{array}$ & $\begin{array}{l}892.7 \\
2\end{array}$ & $\begin{array}{l}3274 . \\
92\end{array}$ & $\begin{array}{l}10549 . \\
66\end{array}$ & $\begin{array}{l}5334 . \\
84\end{array}$ & $\begin{array}{l}46396 . \\
95\end{array}$ \\
\hline
\end{tabular}

$x_{1}=58,98 \%, \mathrm{~s}_{1}^{2}=463.97, \mathrm{~s}_{1}=21.54$

Table 3: English Language Test Scores For Children Who Did Not Undergo The ECD Programme $\left(\mathrm{n}_{2}=\right.$ 100)

\begin{tabular}{|l|l|l|l|l|l|l|l|l|l|l|}
\hline $\begin{array}{l}\text { Score } \\
(\%)\end{array}$ & $0-20$ & $21-30$ & $31-40$ & $41-50$ & $51-60$ & $61-70$ & $71-80$ & $81-90$ & $91-100$ & $\Sigma$ \\
\hline $\begin{array}{l}\text { Mid } \\
\text { Score }(x)\end{array}$ & 10 & 25.5 & 35.5 & 45.5 & 55.5 & 65.5 & 75.5 & 85.5 & 95.5 & 494 \\
\hline $\begin{array}{l}\text { Frequenc } \\
\text { y }(f)\end{array}$ & 13 & 9 & 10 & 14 & 11 & 23 & 4 & 8 & 1 & 100 \\
\hline$f(x)$ & 130 & 229.5 & 355 & 637 & 999 & 1506.5 & 302 & 684 & 95.5 & 4938.5 \\
\hline$(x$-mean) & -39.39 & -23.89 & -13.89 & -3.89 & 6.11 & 16.11 & 26.11 & 36.11 & 46.11 & \\
\hline \begin{tabular}{l}
$(x \text {-mean })^{2}$ \\
\hline
\end{tabular} & 1551.58 & 570.78 & $\begin{array}{l}192.9 \\
3\end{array}$ & 15.13 & 37.33 & 259.53 & 681.73 & 1303.93 & $\begin{array}{l}2126.1 \\
3\end{array}$ & 6739.02 \\
\hline $\begin{array}{l}F(x- \\
\text { mean })^{2}\end{array}$ & $\begin{array}{l}20170.5 \\
4\end{array}$ & $\begin{array}{l}5136.5 \\
9\end{array}$ & $\begin{array}{l}1929 . \\
3\end{array}$ & $\begin{array}{l}211.8 \\
5\end{array}$ & $\begin{array}{l}671.9 \\
8\end{array}$ & $\begin{array}{l}5969.2 \\
4\end{array}$ & $\begin{array}{l}2726.9 \\
3\end{array}$ & $\begin{array}{l}10431.4 \\
6\end{array}$ & $\begin{array}{l}2126.1 \\
3\end{array}$ & 49374.0 \\
2
\end{tabular}

$x_{2}=49,39 \%, S_{2}{ }^{2}=493.74, \quad S_{2}=22.22$

Table 2 shows that the average English Language test score for children who underwent the ECD programme was $58.98 \%$ with a standard deviation of 21.54. From table 3, the average English Language test score was $49,39 \%$ with a standard deviation of 22.22. At descriptive level, children who underwent, the ECD programme in Mzilikazi District performed better in English Language than those who did not. A t-test of independent means confirmed a significant difference in performance in English Language between children who underwent the ECD programme and those who did not at $\alpha=0.05$.

Table 4: Mathematics Test Scores For Children Who Underwent The ECD Programme $\left(\mathbf{n}_{1}=\mathbf{1 0 0}\right)$

\begin{tabular}{|c|c|c|c|c|c|c|c|c|c|c|}
\hline $\begin{array}{l}\text { Score } \\
(\%)\end{array}$ & $0-20$ & $21-30$ & $31-40$ & $41-50$ & $51-60$ & $61-70$ & $71-80$ & $81-90$ & $91-100$ & $\Sigma$ \\
\hline $\begin{array}{l}\text { Mid } \\
\text { Score }(x)\end{array}$ & 10 & 25.5 & 35.5 & 45.5 & 55.5 & 65.5 & 75.5 & 85.5 & 95.5 & 494 \\
\hline $\begin{array}{l}\text { Frequenc } \\
\mathrm{y}(f)\end{array}$ & 1 & 8 & 8 & 11 & 27 & 14 & 13 & 8 & 10 & 100 \\
\hline$f(x)$ & 10 & 204 & 284 & 500.5 & $\begin{array}{c}1498 . \\
5\end{array}$ & 917 & 981.5 & 684 & 955 & 6034.5 \\
\hline$(x$-mean $)$ & -50.3 & -34.8 & -24.8 & -14.8 & -4.8 & 5.2 & 15.2 & 25.2 & 35.2 & \\
\hline$(x \text {-mean })^{2}$ & $\begin{array}{c}2530.0 \\
9\end{array}$ & $\begin{array}{c}1211.0 \\
4\end{array}$ & 615.04 & 219.04 & 23.04 & 27.04 & 213.04 & 635.04 & $\begin{array}{c}1239.0 \\
4\end{array}$ & 6730.41 \\
\hline $\begin{array}{l}F(x- \\
\text { mean })^{2}\end{array}$ & $\begin{array}{c}2530.0 \\
9\end{array}$ & $\begin{array}{c}9688.3 \\
2\end{array}$ & $\begin{array}{c}4920.3 \\
2\end{array}$ & $\begin{array}{c}2409.4 \\
4\end{array}$ & $\begin{array}{c}622.0 \\
8\end{array}$ & $\begin{array}{c}378.5 \\
6\end{array}$ & $\begin{array}{c}3003.5 \\
2\end{array}$ & $\begin{array}{c}5080.3 \\
2\end{array}$ & $\begin{array}{c}12390 . \\
4\end{array}$ & $\begin{array}{c}41023.0 \\
5\end{array}$ \\
\hline
\end{tabular}

$x_{2}=60.35 \%, S_{1}^{2}=410.23, \quad S_{1}=20.25$ 
Effectiveness of the Early Childhood Development Programme on Grade One Performance in

Table 5: Mathematics Test Scores of Children Who Did Not Undergo ECD $\quad\left(n_{2}=100\right)$

\begin{tabular}{|l|c|c|c|c|c|c|c|c|c|c|}
\hline $\begin{array}{l}\text { Score } \\
(\%)\end{array}$ & $0-20$ & $21-30$ & $31-40$ & $41-50$ & $51-60$ & $61-70$ & $71-80$ & $81-90$ & $91-100$ & $\Sigma$ \\
\hline $\begin{array}{l}\text { Mid } \\
\text { Score }(x)\end{array}$ & 10 & 25.5 & 35.5 & 45.5 & 55.5 & 65.5 & 75.5 & 85.5 & 95.5 & 494 \\
\hline $\begin{array}{l}\text { Frequenc } \\
\text { y }(f)\end{array}$ & 0 & 12 & 10 & 11 & 28 & 13 & 9 & 8 & 9 & 100 \\
\hline$f(x)$ & 10 & 306 & 355 & 500.5 & 1554 & 851.5 & 675.5 & 684 & 859.5 & 5790 \\
\hline$(x$-mean $)$ & -47.9 & -32.4 & --22.4 & -12.4 & -2.4 & 7.6 & 17.6 & 27.6 & 37.6 & \\
\hline$(x \text {-mean })^{2}$ & 2294. & 1049.76 & 501.7 & 153.76 & 5.76 & 57.76 & 309.76 & 761.76 & 1413.76 & 6548.4 \\
\hline $\begin{array}{l}F(x- \\
\text { mean })^{2}\end{array}$ & 0 & $\begin{array}{c}12597.1 \\
2\end{array}$ & $\begin{array}{c}5017 . \\
6\end{array}$ & $\begin{array}{c}1691.3 \\
6\end{array}$ & $\begin{array}{c}161.2 \\
8\end{array}$ & $\begin{array}{c}750.8 \\
8\end{array}$ & $\begin{array}{c}2787.8 \\
4\end{array}$ & $\begin{array}{c}6094.0 \\
8\end{array}$ & $\begin{array}{c}12723.8 \\
4\end{array}$ & 41824 \\
\hline
\end{tabular}

$x_{1}=57,9 \%, S_{1}^{2}=418.24, \quad S_{2}=20.45$

Table 4 indicates that the Mathematics average performance score of children who underwent the ECD programme in Mathematics was $60.35 \%$ while in Table 5 those who did not undergo the ECD programme had an average score of $57.9 \%$. The standard deviation for those who underwent the ECD programme was 20.25 while those who did not achieved a standard deviation of 20.45. From the descriptive statistics it appeared that the children who underwent the ECD programme performed better in Mathematics than those who did not. However, at $\alpha=0.05$, the t-test revealed that the difference between the performance scores of the two groups was not statistically significant.

Table 6: Perceptions of Grade One Teacher About the Effectiveness of the ECD Programme on Grade One Performance $(\mathbf{n}=20)$

\begin{tabular}{|l|c|c|c|c|c|c|c|c|c|c|}
\cline { 2 - 10 } \multicolumn{2}{l|}{} & \multicolumn{2}{|c|}{$\mathrm{SA}$} & \multicolumn{2}{|c|}{$\mathrm{A}$} & \multicolumn{2}{c|}{$\mathrm{U}$} & \multicolumn{2}{c|}{$\mathrm{D}$} \\
\cline { 2 - 12 } & $\mathrm{n}$ & $\%$ & $\mathrm{n}$ & $\%$ & $\mathrm{n}$ & $\%$ & $\mathrm{n}$ & $\%$ & $\mathrm{n}$ & $\%$ \\
\hline Children who did ECD perform better in Maths. & 6 & 30 & 5 & 25 & 3 & 15 & 4 & 20 & 2 & 10 \\
\hline Children who did ECD grasp Maths concepts faster & 4 & 20 & 7 & 35 & 3 & 15 & 3 & 15 & 3 & 15 \\
\hline Children who did ECD have better numeracy skills & 5 & 25 & 6 & 30 & 2 & 10 & 4 & 20 & 3 & 15 \\
\hline $\begin{array}{l}\text { There is no difference in performance in Maths between } \\
\text { the two groups }\end{array}$ & 3 & 15 & 3 & 15 & 3 & 15 & 7 & 35 & 4 & 20 \\
\hline $\begin{array}{l}\text { Children who did ECD perform better in English } \\
\text { Language }\end{array}$ & 3 & 15 & 2 & 10 & 10 & 50 & 2 & 10 & 3 & 15 \\
\hline Children who did ECD perform better in spelling & 4 & 20 & 3 & 15 & 8 & 40 & 2 & 10 & 3 & 15 \\
\hline Children who did ECD perform better in word attack & 3 & 15 & 1 & 5 & 12 & 60 & 2 & 10 & 2 & 10 \\
\hline Children who did ECD perform better in reading & 5 & 25 & 3 & 15 & 8 & 40 & 3 & 15 & 1 & 10 \\
\hline $\begin{array}{l}\text { Children who did ECD perform better in sentence } \\
\text { construction }\end{array}$ & 3 & 15 & 3 & 15 & 11 & 55 & 1 & 5 & 2 & 10 \\
\hline There is no difference in performance in English & 4 & 20 & 3 & 15 & 7 & 35 & 4 & 20 & 2 & 10 \\
\hline
\end{tabular}

The pattern portrayed in Table 6 is that many of the grade one teachers either agreed or were uncertain that grade one children who did ECD performed better than those who did not in both English Language and Mathematics. The teachers were uncertain on whether there was no difference between the two groups. Such inconsistencies suggest that the teachers doubted the effectiveness of the ECD programme on grade one performance

Table 7 Perceptions of School Administrators About The Effectiveness of the ECD Programme (n=10)

\begin{tabular}{|c|c|c|c|c|c|c|c|c|c|c|}
\hline & \multicolumn{2}{|c|}{ SA } & \multicolumn{2}{|c|}{$\mathrm{A}$} & \multicolumn{2}{|c|}{$\mathrm{U}$} & \multicolumn{2}{|c|}{$\mathrm{D}$} & \multicolumn{2}{|c|}{ SD } \\
\hline & $\mathrm{n}$ & $\%$ & $\mathrm{n}$ & $\%$ & $\mathrm{n}$ & $\%$ & $\mathrm{n}$ & $\%$ & $\mathrm{n}$ & $\%$ \\
\hline The ECD programme prepares children for Grade one & 7 & 70 & 2 & 20 & 1 & 10 & 0 & 0 & 0 & 0 \\
\hline Grade one performance has improved & 3 & 30 & 2 & 20 & 2 & 20 & 3 & 30 & 0 & 0 \\
\hline Children who did ECD perform better in Maths & 2 & 20 & 2 & 20 & 4 & 40 & 1 & 10 & 1 & 10 \\
\hline Children who did ECD perform better in English & 2 & 20 & 2 & 20 & 4 & 40 & 2 & 20 & 0 & 0 \\
\hline The school has adequate material for ECD & 0 & 0 & 0 & 0 & 1 & 10 & 7 & 70 & 2 & 20 \\
\hline The ECD teachers are appropriately trained & 2 & 20 & 2 & 20 & 1 & 10 & 4 & 40 & 1 & 10 \\
\hline $\begin{array}{l}\text { The ECD curriculum has a link with the Grade one } \\
\text { syllabus }\end{array}$ & 2 & 20 & 2 & 20 & 3 & 30 & 2 & 20 & 1 & 10 \\
\hline $\begin{array}{l}\text { There is appropriate infrastructure for the ECD } \\
\text { programme }\end{array}$ & 0 & 0 & 0 & 0 & 0 & 0 & 8 & 80 & 2 & 20 \\
\hline
\end{tabular}


Table 7 illustrates that the school administrators were generally not sure whether the ECD programme was effective on grade one performance or not. However, on general conditions for the effective ECD programme they were unanimous that such conditions did not exist in the schools.

\section{CONCLUSIONS}

On the basis of the findings of the study, the following conclusions were drawn:-

- At 5\% level of significance, grade one children who underwent the ECD programme performed better in English Language than those who did not.

- At 5\% level of significance, there was no significant difference in performance in Mathematics between grade one children who underwent the ECD programme and those who did not.

- Generally, the ECD programme had potential to improve grade one performance but had resource and process related challenges.

\section{RECOMMENDATIONS}

The study recommended that:-

- The Ministry of Higher and tertiary Education should speed up and expand the training of ECD teachers in colleges and universities.

- The Ministry of Education, Sport and Culture should facilitate regular development workshops for school administrators, ECD and grade one teachers.

- The Curriculum Development Unit should be capacitated to review the ECD syllabus so that it has a deliberate link with the grade one curriculum.

- The Ministry of Education, Sport and Culture should facilitate regular monitoring and evaluation of the ECD programme.

- A national survey of the effectiveness of the ECD programme on grade one performance should be undertaken.

\section{REFERENCES}

[1] Ayasi, R.A. (2003). Put Children First: For Every Child Health, Education, Equity, Protection: Advance Humanity. Harare : UNICEF.

[2] Bernard, H.W. (1973).Child Development and Learning. Boston: Allyn and Bacon.

[3] Curtis, A.M. (1996). A Curriculum For The Pre-School Child: Learning to Learn. London : Routledge.

[4] Dynda, C.; Makoni, R.D.; Mudukuti, A. and Kuyayama, A. (2005). Evaluation Of The National Early Childhood Development Programme. Harare : INICEF.

[5] Feeney, S.; Christensen, D. and Moravick, E. (1991). Who Am I in The Lives of Children? An Introduction to Teaching Young Children. New York : MacMillan.

[6] Government of Zimbabwe Pub. Co. (1987) Education Act (Revised 1992, 1996, 2004). Harare : Government Printers.

[7] Harmse, H. J.; du Toit, M.E. and Broeksman, M.M. (1998). Education For Life. Pretoria : Education Bureau.

[8] Hendrick, S. (1986). The Whole Child : Early Education For The Eightees. Columbus : Charles E. Merrill Pub. Co.

[9] Howes, C. (1986) Keeping Current in Child Care Research : An Annotated Bibliography.Washington D.C. : National Association For The Education of Young Children.

[10] Hurt, C.H.; Charlesworth, R.; Burts, D.C. and DeWolf, M.C. (1993). The Relationship Of

[11] Attendance in Developmentally Appropriate Kindergarten Classroom to First Grade Behaviour. Paper Presented at The Biennial Meeting of The Society For Research in Child Development. New Orleans.

[12] Horst, V. (1991). Planning For Early Learning: Education In The First Five Years. London : Paul Chapman Pub.

[13] Keyton, S. (2001). Communication Research : Asking Questions, Findings Answers. Boston : McGraw-Hall.

[14] MOESC, (2001). Early Childhood Education and Care (ECEC) Syllabus. Harare : Government Printers.

[15] Morrison, G.S. (1988). Early Childhood Education Today. Columbus: Merrill Pub. Co.

[16] NEPI (1992). Early Childhood Educare. Cape Town : OUP.

[17] Nziramasanga, C.T. (1999). Report Of The Presidential Commission Of Inquiry Into Education and Training. Harare : Government Printers.

[18] Papalia, D.E.; Olds, S.W. and Feldman, R.D. (2001). Human Development. New York : McGraw-Hill.

[19] Santrock, J.W. (2002).A Topical Approach To Life-Span Development. Boston: McGraw-Hill.

[20] Smith, E.A. (1994) Educating The Under 5s. London: Cassel.

[21] Smith, P.K. and Cowie, H. (1991) Understanding Children's Development. Oxford : Blackwell.

[22] Taggart, B. and Siraj - Blatchford, I. (2007). A Good Start. The Magazine of The Institute Of Education. Issue 6 (Pages 16-17).

[23] Tassoni, P. (1998) Child Care and Education. Oxford: Heinemann. 